\title{
e Necessity and Implications of ICD-10: Facts and Fallacies
}

\section{TO THE EDITOR:}

In an effort to inform the readership of Pain Physician about the impending conversion to the ICD-10 system, we published a detailed review article on point 1. The final line of the paper was a recommendation to" postpone implementation of ICD-10 and focus rather on core issues of improving care and access."

The Centers for Medicare \& Medicaid Services will require all health professionals and facilities to transition to ICD-10 by October 2013. ICD-10 is viewed as being more nuanced and providing a greater level of detail for what had led to an injury or illness. ICD-9 has 14,000 codes. As outlined in the article, implementing ICD-10 nationally will require a tremendous allocation of resources. The upcoming change would require practices to learn 69,000 new codes for billing purposes.

The American Medical Association (AMA) apparently agrees. During the 65th House of Delegate Interim Meeting of the AMA that occurred on November $15,2011,2$, delegates adopted a policy to work to stop implementation of the new diagnosis coding set ICD10. Alabama and Mississippi delegations, the American Association of Clinical Urologists and the American Urological Association introduced the resolution to stop ICD-10 implementation.

"The implementation of ICD-10 will create significant burdens on the practice of medicine with no direct benefit to individual patients' care," said AMA President Peter W. Carmel, MD. "At a time when we are working to get the best value possible for our health care dollar, this massive and expensive undertaking will add administrative expense and create unnecessary workflow disruptions. The timing could not be worse, as many physicians are working to implement electronic health records into their practices. We will continue working to help physicians keep their focus where it should be -- on their patients" (2).

On February 16th, 2012 Health and Human Services Secretary Kathleen G. Sebelius announced that HHS will initiate a process to postpone the date by which certain health care entities have to comply with imple- mentation of the ICD-10 system. Sebelius said ... "We have heard from many in the provider community who have concerns about the administrative burdens they face in the years ahead. We are committing to work with the provider community to reexamine the pace at which HHS and the nation implement these important improvements to our health care system (3)."

\author{
Joshua A. Hirsch, MD \\ Mass General Hospital \\ GRB 241 \\ Boston, MA 02114 \\ E-mail: HIrsch@snisonline.org \\ Frank Falco, MD \\ Mid Atlantic Spine \\ 139 East Chestnut Hill Road \\ Newark, DE 19713 \\ E-mail: cssm01@aol.com \\ Laxmaiah Manchikanti, MD \\ Medical Director \\ Pain Management Center of Paducah \\ 2831 Lone Oak Road \\ Paducah, KY 42003 \\ E-mail: drlm@thepainmd.com
}

\section{References}

1. Manchikanti L, Falco FJE, Hirsch JA. Necessity and implications of ICD-10: Facts and Fallacies. Pain Physician 2011; 14:E405-E425.

2. AMA Press Release: AMA Adopts New Policies During Final Day of Semi-Annual Meeting. November 15, 2011.

www.amaassn.org/ama/pub/news/ news/2011-11-15-ama-adopts-new-policies.page

3. www.cms.gov/ICDio/Downloads/HHSPressReleaselCD1ofinal321612.pdf 